\title{
Promising targets and current clinical trials in metastatic squamous cell lung cancer
}

\section{Mark D. Vincent*}

London Regional Cancer Program, Department of Medical Oncology, London Health Sciences Centre, London, ON, Canada

Edited by:

Barbara Melosky, British Columbia

Cancer Agency, Canada

\section{Reviewed by:}

Sacha I. Rothschild, University

Hospital Basel, Switzerland

Gregory Alan Otterson, The Ohio

State University, USA

*Correspondence:

Mark D. Vincent, London Regional

Cancer Program, Department of

Medical Oncology, 790

Commissioners Road East, London,

ON N6A 4L6, Canada

e-mail:mark.vincent@Ihsc.on.ca
Squamous cancer of the lung (SOCC), although no longer the premier variant of nonsmall cell lung cancer, continues to impose a heavy world-wide burden. Advanced SOCC has enjoyed little of the recent progress benefiting patients with adenocarcinoma of the lung, but that has now begun to change. This article reviews the underlying molecular pathology of SOCC, as well as potential new targets and the corresponding novel targeted agents; included are some of which may soon be approvable in this notoriously hard-to-treat indication.

Keywords: squamous, epidermoid, lung cancer, systemic treatment, molecular

\section{INTRODUCTION}

Although squamous (epidermoid) lung cancer (SQCC) represents a declining proportion of non-small cell lung cancer (NSCLC), it still represents about $30 \%$ of all NSCLC, and as such, accounted for 6300 of the $\pm 24,700$ new cases of lung cancer in Canada thought to have occurred in 2013 (1). There is little if any comprehensive data on the histologic subtype distribution by stage, but it is possible that SQCC is somewhat more frequent in earlier stages as evidenced by two large Canadian series of stage III NSCLC, in both of which SQCC was the most frequent histological subtype $(2,3)$.

Up to, and including the 1990s, histological subtype was not considered to be particularly relevant in determining either the choice of therapy, or its outcomes, in advanced NSCLC. Of course, it had long been realized that SQCC had certain characteristic clinical features, such as a much higher incidence of hypertrophic pulmonary osteoarthropathy (including "clubbing"), non-metastatic paraneoplastic hypercalcemia and proximally situated, cavitating primary lesions, compared to other types of lung cancer. Furthermore, it had also been well understood that SQCC had a stronger association with smoking than adenocarcinoma (ADC), e.g., for current smokers (RR 16.91 vs. 4.21) (4). Unsurprisingly, SQCC is the histological subtype most associated with emphysema (5).

All of these features, while of great interests to diagnostic physicians and respirologists, may also impact directly or indirectly on the management of advanced NSCLC by oncologists. However, shortly after the turn of the century, it became clear that the histological subtyping of lung cancer had a previously unrecognized importance that went way beyond the fine-tuning of management, and even beyond the important distinction between small cell (SCLC) and NSCLC, which had, heretofore, been the major contribution of pathologists. Two types of new molecularly targeted drugs, gefitinib and bevacizumab, and one new chemotherapeutic, pemetrexed, seemed to have dramatically different effects (either with respect to efficacy or toxicity) according to histology, and the increasingly powerful techniques of genetic sequencing and analysis were revealing that SQCC seemed to be a different molecular entity from other types of lung cancer. In an era in which molecular diagnostics is seen increasingly as a way not only to guide the use of existing therapies but also to select patients for clinical trial accrual, and most critically, as a pathway for novel drug design, the traditional "one size fits all" categorization of advanced NSCLC is increasingly seen as obsolete.

That having been said, it is worth noting that often, definitive biopsy material may not be available, not even for histology let alone molecular tests, and the clinician may be forced to rely on a scant, non-specific cytology specimen ("NSCLC-NOS"), and the clinical features may be the only clue to the true histology. Furthermore, novel immunomodulatory drugs are definitely active in both SQCC and ADC, and for these agents, emerging molecular biomarkers may prove to be more predictive such that histological subtyping of NSCLC may, at least in the immunological arena, again become irrelevant.

\section{CONVENTIONAL PATHOLOGY}

Because histological subtype now profoundly affects clinical management, and because molecular analysis should be routine, at least in non-SQCC, every patient with advanced NSCLC should, if at all possible, be provided with the opportunity to undergo a professional biopsy procedure. Paradoxically, although patients with advanced NSCLC usually have a higher disease bulk and more potential sites for biopsy, they still may be referred in with a sub-optimal, cytology-only fine needle aspirate (FNA) perhaps motivated by risk-avoidance. In skilled hands, and with an adequately cellular FNA, the diagnostic accuracy and value of cytology and a small biopsy are actually comparable and even complimentary (6). Importantly, both cytology and core biopsy can each be used for immunohistochemistry (IHC) and molecular testing for EGFR and KRAS, providing a cell block-sufficient sample 
is obtained. Nonetheless, most pathology departments prefer an adequate core biopsy both for histology (including IHC) and, if indicated, subsequent molecular testing.

It is now generally accepted that only two major types of NSCLC exist, ADC and SQCC, with other types being relatively uncommon (7). SQCC is diagnosed by the presence of keratinization and intercellular bridges, and the absence of features typical of ADC (intracellular mucin and gland formation). If this distinction cannot be rendered by conventional stains, IHC is usually adequate and highly valuable (8). Several investigations have confirmed that cytokeratin 5/6 (CK5/6) and p63 are most useful for SQCC, with a recent study showing for CK $5 / 6$, a sensitivity of $94 \%$, specificity of $97 \%$, PVP of $97 \%$, and PVN of $96 \%$. These values for p63 were 93\% (sensitivity), 87\% (specificity), 96\% (PVP), and 94\% (PVN) (9).

Additional criteria include negativity for the ADC markers of CK7, TTF-1, and Napsin A. Although there is some variability in these results, it should be generally noted the SQCC of the lung are likely to be both CK 5/6 and p63 positive, and negative for TTF-1 or CK7. Novel immune panels continue to be developed, and which may prove superior (10).

\section{MOLECULAR PATHOGENESIS AND TARGETED THERAPY}

The effort to elucidate the molecular abnormalities in cancer is driven not just by curiosity or technical prowess but by a deeply embedded belief system that mutations drive malignant behavior, and that a description of these "driver mutations" will inevitably lead to the design of targeted drugs that are efficacious, via inhibition of the causal chain, and non-toxic, because of the specificity of the mutation for the cancer. Although this paradigm is overly simplistic, it has proven accurate for ADC in respect to EGFR mutations, and translocation of ALK; in both cases, reliable molecular tests are available, which guide the selection of available targeted drugs, which exhibit marked if temporary activity in subgroups of ADC with these genetic alterations. Unfortunately, EGFR and ALK rearrangements have only been described in rare cases of pure SQCC (11-13), but not at a frequency that would justify testing for either mutation routinely. Furthermore, at least in the case of those rare pure SQCCs with mutated EGFR, the targeted first generation tyrosine kinase inhibitors (EGFR-TKIs) seen to be somewhat less active than in ADC with mutated EGFR (12). Consequently, unless there is pathological evidence of a mixed adeno-squamous pathology (in which case it is worth testing) (14), it is not cost-beneficial to submit SQCCs (nor, probably, "NOS - probably squamous") cases for molecular analysis.

Likewise, KRAS mutations, which are common in (ex-) smokers with ADC, are only occasionally detected in SQCC $(6.4 \%$ in the West, $1.8 \%$ in Asia) (15). KRAS in any event remains directly undruggable, but some believe that NSCLC patients with KRAS mutations may be less responsive to EGFR-TKIs (16). If true, this could explain why SQCCs do relatively well on EGFR-TKIs, despite the absence of EGRF mutations (17).

Squamous (epidermoid) lung cancer, despite the general absence of EGFR, ALK, and KRAS mutations, is genomically speaking, a highly aberrant malignancy (18). This is likely related to its close association with tobacco smoke, which contains over
5000 identified compounds, of which 73 are known carcinogens (19). These compounds form DNA adducts once metabolically activated. Unless repaired, these DNA lesions cause permanent mutations in the complementary strand due to bypass polymerases "inserting the wrong base opposite the adduct" (19). As a result of long-term exposure, thousands of mutations occur in the respiratory cells of smokers, some of which affect the function of growth regulatory genes. A variety of other processes facilitate tumorigenesis, such as inflammatory generation of reactive oxygen species and gene promoter methylation.

The Cancer Genome Atlas Research Network (CGARN) study on lung SQCC revealed many varied DNA alterations (“... a mean of 360 exonic mutations, 323 altered copy number segments and 165 genomic rearrangements per tumor") (18). Importantly, copy number aberrations do not necessarily imply point mutations in the DNA sequence. The mean rate of exonic somatic mutations was, at 8.1 mutations per megabase, higher than any other cancer type except melanoma. TP53 mutations occurred in at least $81 \%$ of 178 samples of SQCC; TP53 is well known as the "guardian of the genome." Other mutations occurred quite often in pathways felt to be important in the mediation of the malignant phenotype, e.g., oxidative stress (KEAP1, 12\%, CUL3, 7\%, and NFE 2L2, 19\%); squamous differentiation (SOX2, 21\%; TP63, $16 \%$; NOTCH 1 and 2, $8 \%$ and 5\%, respectively; ASCL4, $3 \%$; and FOXP 1, 4\%). mRNA expression profiling revealed overexpression of SOX2, TP63, and P1K3CA, corresponding to the known 3q26 chromosomal amplicon. The p40 version of p63 may act as an oncogene, expressed by $89 \%$ of tumors; RB1 and PTEN (loss-offunction) were also frequent. Amplification or alteration of FGFR 1,2 , and 3 were seen in 7,3 , and $2 \%$, respectively, as well as others involved in PI3K/RTK/RAS signaling (EGFR 9\%; ERB B2 4\%; ERB B3 2\%; PTEN 15\%; PIK3CA 16\%; AKT3 16\%; STK 11, 2\%; TSC 1 and 2, 3\% each; KRAS 3\%; HRAS 3\%; NF1 11\%; RASA $14 \%$; BRAF, $4 \%$ ).

CDKN2A, a "known tumor suppressor gene," encodes INK $4 \mathrm{~A} / \mathrm{p} 16$ and ARF/p14, which control the cell cycle. This gene is inactivated in $77 \%$ of SQCCs (by a variety of mechanisms), often by epigenetic silencing (21\%) or homozygous deletions (19\%). On the other hand, about $30 \%$ overexpress both p16 and p14; often with mutation (see Tables 1 and 2 ).

These changes were seen against a background of a high mutational load in apparently non-contributory genes.

The authors contemplated the totality of this picture in terms of potential therapeutic targets. They felt the location of mutations in key cancer genes, such as a variety of tyrosine kinases, serine/threonine kinases, $\mathrm{PI} 3 \mathrm{~K}$ regions, proteases, and G-protein coupled receptors, suggested potential therapeutic targets. Unfortunately, however, many of the mutations were inactivations of tumor suppressor genes, which are currently not directly druggable. FGFR alterations, however, are among the most promising, and have recently been extensively reviewed in Ref. (20).

FGFR fibroblast growth factor receptor, is a family of 4 kinase receptors (FGFR 1-4) spanning the cell membrane and involved in signal transduction via downstream RAS/MAPK and PI3K/AKT pathways. In normal physiology, FGFR signaling is involved in angiogenesis and organogenesis. In lung cancer, serum FGF levels 
Table 1 | Selected genomic alterations in SqCC

\begin{tabular}{|c|c|c|c|c|c|}
\hline & Gene & Mutation rate & Normal function & Consequence of alteration & Comment \\
\hline (a) & KEAP1 & $12 \%$ & Oxidative stress response & Loss-of-function & \\
\hline (a) & NFE2L2 & $19 \%$ & Oxidative stress response & Activation & \\
\hline (a) & CUL3 & $7 \%$ & Oxidative stress response & Loss-of-function & \\
\hline (b) & SOX2 & Zero & Squamous differentiation & Activation & Amplified in $21 \%$ \\
\hline (b) & NOTCH1 & $8 \%$ & Squamous differentiation & Mostly loss-of-function & $\begin{array}{l}\text { Mutually exclusive with } \\
\text { TP63 or SOX2 alterations }\end{array}$ \\
\hline (b) & TP63 (p40 isoform) & $16 \%$ & Squamous differentiation & Activation, oncogene & \\
\hline (c) & TP53 & $\geq 81 \%$ & Genomic integrity, apoptosis & Loss-of-function & Disabled in $~ 90 \%$ SqCC \\
\hline (d) & CDKN2A & $15 \%$ & Cell cycle control & Loss-of-function & $\begin{array}{l}\text { Inactivated in } 72 \% \text { by } \\
\text { several mechanisms }\end{array}$ \\
\hline (d) & RB1 & $7 \%$ & Cell cycle control & Loss-of-function & $\begin{array}{l}\text { Mutually exclusive with } \\
\text { CDKN2A alterations }\end{array}$ \\
\hline (e) & NF1 & $11 \%$ & RAS inhibitor & Loss-of-function & \\
\hline (e) & BRAF & $4 \%$ & Signal transduction & Activation & \\
\hline (e) & RASA1 & $4 \%$ & RAS inhibitor & Loss-of-function & \\
\hline (e) & KRAS & $<1 \%$ & Signal transduction & Activation & Very uncommon in SqCC \\
\hline (f) & HLA-A & $3 \%$ & Antigen display & Loss-of-function & $\begin{array}{l}\text { May permit avoidance of } \\
\text { immune destruction }\end{array}$ \\
\hline (g) & PTEN & $8 \%$ & PI3K/Akt pathway inhibitor & Loss-of-function & \\
\hline (g) & PIK3CA & $16 \%$ & PI3K/Akt pathway growth and survival & Activation & AKT3 also activated in $16 \%$ \\
\hline (h) & FGFR1 & Few & RTK growth/survival & Activation & Amplified in $21 \%$ \\
\hline (h) & EGFR & $\begin{array}{l} \pm 1 \% \text { L8610 } \\
\text { mutation rate }\end{array}$ & RTK in growth/survival growth function & Activation & $\begin{array}{l}\text { Amplified in 9\%, rarely } \\
\text { mutated }\end{array}$ \\
\hline (i) & MLL2 & $20 \%$ & Chromatin regulation & $?$ & \\
\hline
\end{tabular}

are known to be elevated. Amplification of FGFR 1 may be characteristic of SQCC. The prognostic and predictive significance of these pathway alterations remains under investigation, but the bulk of evidence seems to suggest over-activity correlates with a poorer outcome.

The preclinical data have been sufficiently compelling to warrant the design and trialing of small molecules with FGFR inhibitory activity, including cediranib, nintedanib, pazopanib, and ponatinib. Nintedanib (an inhibitor of VEGFR 1-3, FGFR 1-4, PDGFR, FLT-3, and src), is most advanced, with a positive randomized trial (LUME - Lung 1) in second line (docetaxel \pm nintedanib) (21). About $42 \%$ of the patients had SQCC; in these, the PFS HR 0.77 was significant $(p=0.02)$, as it was in the ADC subgroup (HR $0.77 p=0.0193$ ). Disease control was superior in the SQCC patients $(49.3 \%$ vs. $35.5 \%, p<0.0001)$. However, the effect on overall survival (OS) (in an exploratory analysis) seemed better in ADC than SQCC. Nintedanib appears tolerable, with GI and liver function abnormalities being most prominent. An excess of $12.3 \%$ of the patients required a dose reduction over placebo. LUME-Lung 3 is a first-line phase I/II trial of nintedanib with cisplatin/gemcitabine (NCT01346540).

Ponatinib is undergoing a phase II in SQCC as monotherapy after prior treatment, with FGFR amplification as an eligibility requirement (NCT01761747). A randomized trial of first-line carboplatin/paclitaxel \pm cediranib was halted early for futility (22). Cediranib, however, has much less FGFR inhibitory activity than VEGFR blockade.

Pazopanib, another broad-spectrum kinase inhibitor whose actions include FGFR blockade as ancillary to VFGFR inhibition (23), is in a range of trials in A-NSCLC as monotherapy maintenance after first-line chemotherapy (NCT01208064) and with a variety of other traditional drugs in phase II. Other FGFR inhibitors include AZD4547 and BGJ398 and both are in phase I and/or phase II. FP-1039 is a FGF ligand trap also in phase I.

A series from the Massachusetts General Hospital found 16\% of 226 SQCCs exhibited FGFR 1 amplifications, but these were not associated with any particular clinical features, suggesting that molecular testing would be required as a biomarker. Furthermore, the amplification was focal (24).

Looking more broadly at the pathway level, the CGARN found, in their 178 SQCC, $69 \%$ had an alteration in one of the PI3K/AKT, RTK, or RAS pathways, when considering either mutation in the DNA or amplification. For instance, $26 \%$ had either EGFR amplification, an activating BRAF mutation or FGFR 1 amplification, any of which might be targetable by an inhibitory drug. As noted, in the Canadian BR21 trial of erlotinib (an EGFR-TKI) vs. placebo, 
Table 2 | Alterations in major pathways in SqCC

\begin{tabular}{|c|c|c|c|c|}
\hline Gene & $\begin{array}{l}\text { Direction of } \\
\text { dysregulation }\end{array}$ & Incidence & $\begin{array}{l}\text { Normal } \\
\text { function }\end{array}$ & $\begin{array}{l}\text { Current } \\
\text { targetability }\end{array}$ \\
\hline EGFR & $\uparrow$ & $9 \%$ & \multirow{6}{*}{$\begin{array}{l}\text { Receptor } \\
\text { tyrosine } \\
\text { kinase: } \\
26 \%\end{array}$} & \multirow{6}{*}{$\begin{array}{l}\text { (Potentially } \\
\text { targetable) }\end{array}$} \\
\hline ERBB2 & $\uparrow$ & $4 \%$ & & \\
\hline ERBB3 & $\uparrow$ & $2 \%$ & & \\
\hline FGFR1 & $\uparrow$ & $7 \%$ & & \\
\hline FGFR2 & $\uparrow$ & $3 \%$ & & \\
\hline FGFR3 & $\uparrow$ & $2 \%$ & & \\
\hline KRAS & $\uparrow$ & $3 \%$ & \multirow{5}{*}{$\begin{array}{l}\text { RAS/RAF: } \\
24 \%\end{array}$} & \multirow{5}{*}{$\begin{array}{l}\text { (Potentially } \\
\text { targetable) }\end{array}$} \\
\hline HRAS & $\uparrow$ & $3 \%$ & & \\
\hline NRAS & $\uparrow$ & $<1 \%$ & & \\
\hline RASA1 & $\downarrow$ & $4 \%$ & & \\
\hline NF1 & $\uparrow$ & $11 \%$ & & \\
\hline PIK3CA & $\uparrow$ & $16 \%$ & \multirow{4}{*}{$\begin{array}{l}\text { PI3K/AKT: } \\
47 \%\end{array}$} & \multirow{4}{*}{$\begin{array}{l}\text { (Potentially } \\
\text { targetable) }\end{array}$} \\
\hline AKT2 & $\uparrow$ & $4 \%$ & & \\
\hline АКT3 & $\uparrow$ & $16 \%$ & & \\
\hline PTEN & $\downarrow$ & $15 \%$ & & \\
\hline $\begin{array}{l}\mathrm{CDKN}_{2} \mathrm{~A} \\
\text { methylation }\end{array}$ & $\downarrow$ & $21 \%$ & \multirow{5}{*}{$\begin{array}{l}\mathrm{CDKN}_{2} \mathrm{~A}: \\
72 \%\end{array}$} & \multirow{5}{*}{$\begin{array}{l}\text { (Not currently } \\
\text { targetable) }\end{array}$} \\
\hline $\mathrm{CDKN}_{2} \mathrm{~A}$ & $\downarrow$ & $18 \%$ & & \\
\hline mutation & & & & \\
\hline $\begin{array}{l}\mathrm{CDKN}_{2} \mathrm{~A} \text { Exon } \\
\text { skip. }\end{array}$ & $\downarrow$ & $4 \%$ & & \\
\hline $\begin{array}{l}\mathrm{CDKN}_{2} \mathrm{~A} \text { Hom } \\
\text { del }\end{array}$ & $\downarrow$ & $29 \%$ & & \\
\hline
\end{tabular}

the HR in favor of drug was 0.66 in SQCC with a smoking history, almost certainly due to the driver activity of wild-type EGFR (which is quite often overexpressed at the protein level) (25).

Finally, a significant proportion of specimens contained inactivating mutations in the HLA-A gene; this might convey resistance to emerging immunomodulatory regimens. It should also be noted that human papilloma virus, a known carcinogen in the urogenital tract, and in upper respiratory epithelium, has been ruled out as instrumental in lung cancer (26).

Targetable genetic alterations in SQCC were also reviewed recently by Heist et al. from the Massachusetts General Hospital (27), emphasizing that inactivated tumor suppressor genes (tsgs) can only, if at all, be indirectly targeted. They focus on commonly mutated genes (TP53, GRM8, BAI3, ERBB4, RUNX1T1, KEAP1, FBXW7, and KRAS) while noting no currently available agents directed at these mutations. However, they do highlight genomic amplifications and areas of overexpression, which, whether mutated or not, are likely implicated as "drivers," including SOX2 (amplified in 20\% of SQCC; and a key stem cell regulator; no drugs in development); PIK3CA, affecting cell survival and proliferation (copy no. gains in $>20 \%$ SQCCs, mutated in 6.5\%) for which several drugs are in development (Table 3), especially buparlisib, which is in phase II and GDC-0032; and FGFR 1 (discussed above, and mediating growth, survival, and angiogenesis, for which several drugs are in development e.g., AZ4547 a specific FGFR 1-3 blocker). Although available drugs (apart from AZ4547)
Table 3 | Molecularly targeted drugs under investigation in Sqcc ${ }^{\mathrm{a}}$

\begin{tabular}{ll}
\hline FGFR inhibitors & Cediranib; nintedanib; pazopanib; ponatinib; \\
& AZD4547; BGJ398; FP-1039 \\
EGFR inhibitor & Afatinib; necitumumab \\
PIK3CA & Buparlisib; GDC-0032 \\
CDK 4/6 & Palbociclib \\
VEGF-R & Ramucirumab, motesanib \\
PARP & Veliparib \\
Clusterin & Custirsen
\end{tabular}

a Some of these agents have multiple other mechanisms of action in addition.

inhibit more than just the FGFR system, preclinical work confirms that pure inhibitors of FGFR 1 will inhibit growth of FGFR1 amplified tumor cell lines; IGF1R (insulin-like growth factor receptor) is overexpressed in some SQCCs, acting via the canonical growth and survival pathways, but promising phase II results in SQCC lung were not replicated in two phase III trials of figitumumab (a monoclonal antibody against IGF1R).

Other promising targets include EphA2 (overexpression increases invasiveness, and dasatinib is an available inhibitor); MET (amplified in about 6\% of SQCCs, and mediating proliferation and invasion; multiple small molecules and antibodies are in development, but recently a large phase III trial of erlotinib \pm onartuzumab failed, despite a prior highly promising randomized phase II in MET overexpressors (28). A platinum/paclitaxel \pm onartuzumab randomized phase II is pending (NCT01519804). Rilotumumab, an inhibitor of the MET ligand $\mathrm{HGF} / \mathrm{SF}$, is also of interest. Other targets of promise include PDGFRA (amplified in $8-10 \%$ of SQCC; sunitinib an available inhibitor); p53/MDM2 (p53 mutations in about $65 \%$ of SQCCs, mostly loss-of-function; alternatively, MDM2 overexpression can inactivate $\mathrm{p} 53$, as in about 7\% of SQCC; no drugs yet in development); AKT(mutated in about 5\% of SQCCs; several drugs in development); DDR2 (a RTK promoting migration, proliferation, and survival, and mutated in about $4 \%$ of SQCCs; dasatinib may be active); LKB1 (a cell cycle regulator, inactivated in 5-20\%; not yet drugged); PTEN (a tsg, and negative regulator of PI3K/AKT, which is then de-repressed when PTEN inactivated, very frequent in both types of NSCLC, especially SQCC; PI3K inhibitors are logical here); NRF2/KEAP1 (an oxidative stress response system; KEAP1 negatively regulates NRF2, and dysregulation of either gene is common in SQCC; no drugs in development yet).

The cyclin-dependent kinases, CDK 4 and 6 are another target of interest and the inhibitor palbociclib (PD-0332991) is in phase II in SQCC.

EGFR is commonly overexpressed (but rarely mutated) in SQCC. The overexpression may be associated with amplification or polysomy (29-31). FLEX, a first-line phase III trial of cisplatin/vinorelbine \pm cetuximab, was especially positive in both types of NSCLC if, in an explanatory analysis, EGFR was overexpressed by IHC, independent of mutation status (32, 33), but this remains controversial. As noted, BR.21, a lastline study of erlotinib vs. placebo, showed a beneficial HR 
0.67 for SQCC. A 545 patient, first-line phase III trial of cisplatin/gemcitabine \pm necitumumab, a novel, fully human $\lg \mathrm{G} 1$ monoclonal antibody, has just been reported as positive for OS (median survival 11.5 vs. 9.9 months, HR $0.84, p=0.012$ ). Oneand 2-year survival also favored the necitumumab arm (34). Patients $<70$ years seemed to fare better, but the H-score biomarker seemed to exhibit at most a trend for more benefit at higher levels of EGRF expression. Another (phase II) RCT is testing carboplatin/paclitaxel \pm necitumumab in first-line SQCC (NCT0176939). Some $\pm 5 \%$ patients with SQCC exhibit a truncated form of EGFR known as EGFR-vIII, which is transforming, but which lacks an extra-cellular domain, and may be less amenable to inhibition by antibody. Lux-Lung 8 is an ongoing phase III study of a novel, pan-HER, irreversible inhibitor afatinib, vs. erlotinib, in last-line SQCC, and initial reports indicate a modest superiority over erlotinib (35). It remains an open question as to whether EGFR by IHC or gene copy number, can suffice as a biomarker for benefit from anti-EGFR agents in SQCC.

The VEGF/VEGFR angiogenesis pathway is clearly implicated in SQCC progression (36). Bevacizumab, a VEGF-sequestration antibody, caused an unacceptable rate of fatal hemoptysis in SQCC (37). Whether this relates to the tendency of SQCC to have cavitating primaries close to major airways, or some more complex association with squamous histology, is still unresolved; however, bevacizumab was only approved for use in non-SQCCs, for safety reasons. Bevacizumab may well be active in SQCCs and may be safer in patients with excised primaries; this is not known and would be off-label.

Ramucirumab, a fully human $\lg G 1$ monoclonal antibody to VEGRF-2, was recently the subject of a randomized phase III trial (REVEL: docetaxel \pm ramucirumab) in second-line NSCLC including SQCC. It was positive for OS; REVEL included 328 SQCC patients, who experienced a modest OS benefit (9.5 vs. 8.2 months, HR 0.88 ) in a subgroup analysis (38). Motesanib, a small molecule VEGF-R inhibitor, seemed ineffective and prohibitively toxic in a recent randomized trial (39).

It is noteworthy that the successful RCTs in SQCC involve agents not directed at mutated proteins, but at normal components of upregulated pathways in which the specificity arises from contextual, causal dependence rather than biomolecular structural differences. Furthermore, as is usual, the benefits, albeit welcome, appear to be temporary. With the exception of chronic myeloid leukemia and bcr-abl inhibitors, targeted drugs based on the molecular causality principle have uniformly provided only temporary benefit.

\section{RECOGNITION-BASED TARGETING}

Interference in the causal chain mediating malignancy is not the only way to target cancer; another way is based on the principle of recognition. The immune system exploits this to protect us very effectively against foreign organisms, and also, cellular transformation; its direct targets are surface-based biomolecular differences ("markers"), irrespective of whether they are causally important drivers or not. Until recently, it was quite erroneously believed that most cancers were not "antigenic enough" to evolve an effective immune response (IR); however, it is now appreciated that the problem is more that the local milieu within the tumor environment is immunosuppressive, partly because of the manipulation of the immune system by negative regulators expressed on the tumor cells, and (still under-appreciated) the highly proteolytic and extremely acidotic extra-cellular milieu in tumors (40), which is likely to damage the three-dimensional structure of extra-cellular recognition peptides on which the IR is utterly dependent.

Squamous (epidermoid) lung cancer cells, by virtue of the very high mutation burden, are likely to express altered proteins as efficient neoantigens in the context of HLA. (The latter, as noted, may be mutated, potentially compromising antigen presentation in SQCC.) New immunomodulatory agents, also known as "immune checkpoint inhibitors," which have proven effective in both forms of lung cancer (as well as melanoma), derive from an understanding of the "immunological synapse" (41), a complex network of positive and negative regulatory interactions that occur among the tumor cells, the dendritic antigen-presenting cells and the $\mathrm{T}$ lymphocytes, and which strongly influence whether these effector (cytotoxic) T-cells are activated or not.

So far, useful therapies have been developed to block CTLA4 (an early negative regulator on T-cells, active in draining lymph nodes), with a monoclonal antibody, and the PD-L1/PD1 interaction (with monoclonal antibodies directed against either the PD-1 negative regulator on the T lymphocytes, or the PD-L1 ligand on the tumor cell, including SQCC cells, or dendritic cell). This system acts later in the "cancer-immunity cycle," (42), in the actual tumor milieu. Monoclonal antibodies against all three targets have shown surprising activity in lung cancer, and are in accelerated development; side effects have generally been tolerable, with a range of auto-immune effects, more associated with the anti-CTLA4 monoclonal antibody ipilimumab, and rare but potentially serious pneumonitis with the prominent anti PD-1 agent nivolumab.

The CA184-041 study tested two regimens of combination ipilimumab with chemotherapy (concurrent or phased) vs. chemotherapy only; the phased (but not the concurrent) PFS was significantly superior to the chemotherapy only arm. The SQCC patients seemed to benefit more (HR 0.48 for OS) (43). NCT01285609, an ongoing phase III, tests the combination vs. chemotherapy in first-line SQCC, using the apparently superior phased regimen.

The anti-PD1 agent nivolumab achieved a 6/18 ORR (SQCC) in a phase I study; despite heavy pre-treatment, OS at 2 years was $24 \%$ across all 129 NSCLC patients (44). NCT01721759 is an ongoing phase II in SQCC (third line). A phase III in SQCC (nivolumab vs. docetaxel) is underway (NCT01642004), as are phase I trials in A-NSCLC with the various platinum doublets, and also in the highly promising combination with ipilimumab. The role of tumor cell expression of PD-L1 as a biomarker is being investigated in these studies. MK-3475 in another anti-PD1 monoclonal antibody with a 2/6 ORR in SQCC, being moved into phase II/III (NCT01905657), and another pending phase III (NCT0214738), also focused on PD-L1 expressing tumors.

Several anti-PD-L1 antibodies have also shown some activity against SQCC such as BMS-936559 (45). MPDL3280A is 
Table 4 | Checkpoint inhibitors under evaluation in advanced SqCC (selected studies).

\begin{tabular}{|c|c|c|c|c|c|}
\hline $\begin{array}{l}\text { Clinical Trials.gove Identifier, } \\
\text { agent, trial name }\end{array}$ & Target & Phase & Line & Design & Status \\
\hline $\begin{array}{l}\text { NCT01285609 } \\
\text { Ipilimumab }\end{array}$ & CTLA-4 & III & $1 \mathrm{st}$ & Carboplatin/paclitaxel \pm Ipilimumab & Recruiting \\
\hline $\begin{array}{l}\text { NCT01721759 } \\
\text { Nivolumab } \\
\text { Checkmate } 063\end{array}$ & PD-1 & $\|$ & 3rd & Single agent nivolumab & $\begin{array}{l}\text { Active, not } \\
\text { recruiting }\end{array}$ \\
\hline $\begin{array}{l}\text { NCT01642004 } \\
\text { Nivolumab } \\
\text { Checkmate } 017\end{array}$ & PD-1 & III & $>1 \mathrm{st}$ & Nivolumab vs. docetaxel & $\begin{array}{l}\text { Active, not } \\
\text { recruiting }\end{array}$ \\
\hline $\begin{array}{l}\text { NCT02041533 } \\
\text { Nivolumab } \\
\text { Checkmate } 026\end{array}$ & PD-1 & III & $1 \mathrm{st}$ & Nivolumab vs. investigator's choice chemotherapy & Recruiting \\
\hline $\begin{array}{l}\text { NCT01454102 } \\
\text { Nivolumab } \\
\text { Checkmate } 012\end{array}$ & PD-1 & I & Multiple & $\begin{array}{l}\text { Nivolumab with various platinum doublets and/or } \\
\text { biologicals/targeted agents including ipilimumab, } \\
\text { erlotinib }\end{array}$ & Recruiting \\
\hline $\begin{array}{l}\text { NCT01295827 } \\
\text { Pembrolizumab } \\
\text { KEYNOTE } 001\end{array}$ & PD-1 & $\mid / I I$ & $\geq 1 \mathrm{st}$ & Low and high doses, q2 and 3 week schedule & $\begin{array}{l}\text { Active, not } \\
\text { recruiting }\end{array}$ \\
\hline $\begin{array}{l}\text { NCT02220894 } \\
\text { Pembrolizumab } \\
\text { KEYNOTE } 042\end{array}$ & PD-1 & III & $1 \mathrm{st}$ & $\begin{array}{l}\text { Pembrolizumab vs. carboplatin/paclitaxel (or } \\
\text { pemetrexed) }\end{array}$ & Not yet open \\
\hline $\begin{array}{l}\text { NCT02039674 } \\
\text { Pembrolizumab } \\
\text { KEYNOTE } 021\end{array}$ & PD-1 & $|/| \mid$ & $\geq 1$ st & $\begin{array}{l}\text { Pembrolizumab with various platinum doublets } \\
\text { and/or biologicals/targeted agents }\end{array}$ & Recruiting \\
\hline $\begin{array}{l}\text { NCT02007070 } \\
\text { Pembrolizumab } \\
\text { KEYNOTE } 025\end{array}$ & PD-1 & $\|$ & 2 nd & Single agent & $\begin{array}{l}\text { Recruiting } \\
\text { PTO }\end{array}$ \\
\hline $\begin{array}{l}\text { NCT01905657 } \\
\text { Pembrolizumab } \\
\text { KEYNOTE } 010\end{array}$ & PD-1 & $\|/\|$ & $\geq 2$ nd & 2 doses of Pembrolizumab vs. docetaxel & Recruiting \\
\hline $\begin{array}{l}\text { NCT0214738 } \\
\text { Pembrolizumab } \\
\text { KEYNOTE } 024\end{array}$ & PD-1 & III & $1 \mathrm{st}$ & Pembrolizumab vs. platinum doublet & $\begin{array}{l}\text { Not yet } \\
\text { recruiting }\end{array}$ \\
\hline $\begin{array}{l}\text { NCT01846416 } \\
\text { MPDL3280A } \\
\text { FIR }\end{array}$ & PD-L1 & $\|$ & $\geq 1 \mathrm{st}$ & Single agent & $\begin{array}{l}\text { Active, not } \\
\text { recruiting }\end{array}$ \\
\hline $\begin{array}{l}\text { NCT02031458 } \\
\text { MPDL3280A } \\
\text { BIRCH }\end{array}$ & PD-L1 & $\|$ & $\geq 1 \mathrm{st}$ & Single agent & Recruiting \\
\hline $\begin{array}{l}\text { NCT01903993 } \\
\text { MPDL3280A } \\
\text { POPLAR }\end{array}$ & PD-L1 & Random II & 2nd & MPDL3280A vs. docetaxel & $\begin{array}{l}\text { Active, not } \\
\text { recruiting }\end{array}$ \\
\hline NCT02008227 & PD-L1 & III & $2 \mathrm{nd}$ & MPDL3280A vs. docetaxel & Recruiting \\
\hline MPDL3280A & & & & & \\
\hline
\end{tabular}


Table 4 | Continued

\begin{tabular}{|c|c|c|c|c|c|}
\hline $\begin{array}{l}\text { Clinical Trials.gove Identifier, } \\
\text { agent, trial name }\end{array}$ & Target & Phase & Line & Design & Status \\
\hline $\begin{array}{l}\text { NCT02087423 } \\
\text { MEDI4736 }\end{array}$ & PD-L1 & $\|$ & $3 r d$ & Single agent & Recruiting \\
\hline $\begin{array}{l}\text { NCT02000947 } \\
\text { MEDI4736 }\end{array}$ & PD-L1 & I & $\geq 1 \mathrm{st}$ & MEDI4736 with Tremelimumab & Recruiting \\
\hline $\begin{array}{l}\text { NCT02087423 } \\
\text { MEDI4736 } \\
\text { ATLANTIC }\end{array}$ & PD-L1 & $\|$ & $3 r d$ & Single agent & Recruiting \\
\hline
\end{tabular}

Ref for this table: Clinical Trials.gov accessed 31 August 2014.

another anti-PD-L1 monoclonal with early demonstrated activity in SQCC $(3 / 20)$, especially associated with IHC positivity of PD-L1 (46). NCT01903993 will compare MPDL3280A with docetaxel in 2L, followed by the phase III (NCT02008227). MEDI4736 is another anti PD-L1 agent entering phase II in advanced NSCLC (ATLANTIC NCT02087423) and phase III in stage III (PACIFIC), including SQCC.

Readers are referred to two excellent overviews for further details $(47,48)$, and to Table 4.

\section{BONE METASTASES}

Bone metastases may occur in any type of lung cancer, and two categories of drugs have shown efficacy in reducing skeletal-related events (SREs). The bisphosphonate zoledronic acid (49-51) is well studied, and patients with elevated osteoclast marker (Ntelopeptide of type 1 collagen) appear to experience an OS benefit (52). Denosumab, a monoclonal antibody against RANK-ligand, an osteoclast activator, led to an OS benefit compared with zoledronic acid, in a large NSCLC subgroup analysis (51) (HR 0.78, $p=0.01)$ in which the biggest benefit was experienced by SQCC (HR $0.68 p=0.035$ ), and also which was associated with a lower incidence of SREs than zoledronic acid (53).

\section{CHEMOTHERAPY}

No particular third-generation platinum doublet stands out as clearly superior in advanced SQCC, and the decision should be made based on toxicity avoidance (54). In a subgroup analysis of ECOG1594, a large four-armed phase III of taxane and gemcitabine platinum doublets, cisplatin/gemcitabine had the best PFS (4.3 months) and OS (9.4 months) in SQCC, but the differences were not statistically significant. Pemetrexed, however, whether as a single agent or in combination with cisplatin, is inferior and contra-indicated in SQCC, despite its superiority in ADC and large cell $(55,56)$. Pemetrexed is also ineffective in prolonging either PFS of OS in maintenance in SQCC, in contrast to nonSQCC (57). Pemetrexed may be less efficacious in SQCC because of higher thymidylate synthase levels $(58,59)$, although differential expression of the folate receptor alpha may also be important (60).
Nab-paclitaxel with carboplatin appears to be superior to paclitaxel/carboplatin in SQCC, with a higher ORR and less grades 3/4 neuropathy and arthralgia in SQCC (61). Neither PFS nor OS were different. The $41 \%$ ORR for the nab-paclitaxel arm is notable, as it was independently reviewed in Ref. (62).

In Japan, the LETS phase III study demonstrated the superiority of carboplatin/S-1 over carboplatin/paclitaxel in SQCC (HR $0.713 ; 14.0$ vs. 10.6 months) (63). S1 is an oral fluoropyridine.

Further improvements in chemotherapy are unlikely to emerge without the addition of biologicals, some of which have been detailed above. One additional possibility relates to PARP inhibitors. PARP (poly ADP-ribose polymerase) is an enzyme that participates in several DNA repair pathways (64) and is believed to be important particularly in SQCC (65). An initial randomized phase II experience suggested significant benefit in SQCC with veliparib, a PARP inhibitor (PFS HR 0.50) OS HR 0.72), when added to carboplatin/paclitaxel (66) NCT01560104, a phase III trial of first-line platinum chemotherapy, \pm veliparib (ABT-888), is currently underway. An earlier trial of chemotherapy \pm iniparib failed, probably because iniparib might not be a sufficiently active PARP inhibitor (67).

The efficacy of chemotherapy may be also be attenuated by anti-apoptotic (pro-survival) proteins like clusterin, expressed in about $70 \%$ of NSCLC, apparently unrelated to histological subtype $(68,69)$. A phase I/II trial of platinum/gemcitabine with clusterin, a 2.0 generation antisense oligonucleotide, achieved an OS of 14.1 months, which was thought sufficient to justify the phase III trial now underway.

\section{CONCLUSION}

The proportionate reduction in SQCC is likely to be the result of an ongoing reduction in cigarette smoking (70); however, as long as tobacco products (and, probably, marijuana) (71) are consumed, this disease will be a major public health concern. Although most of the progress in lung cancer in the last decade has occurred in ADC, a recent spate of positive trials has, at last, brightened the prospects for SQCC. OS gains have been shown for ramucirumab, necitumumab, cetuximab, denosumab, and nintedanib 
(to be prospectively confirmed); although these results are modest, they do provide a foundation upon which to explore novel biomarkers and potentially synergistic drug combinations. Furthermore, immunomodulators such as anti-PD-1/PD-L1 agents are unquestionably active. The rapidly expanding trove of knowledge on the volatile genome of SQCC has thrown up some further target opportunities, such as the FGFR family. This progress will likely serve to push the 1-year median OS consistently through the 1-year barrier; beyond that, further radical innovation will be necessary.

\section{REFERENCES}

1. Canadian Cancer Society's Advisory Committee on Cancer Statistics. Canadian Cancer Statistics 2013. Toronto, ON: Canadian Cancer Society (2013).

2. Waters E, Dingle B, Rodrigues G, Vincent M, Ash R, Dar R, et al. Analysis of a novel protocol of combined induction chemotherapy and concurrent chemoradiation in unresected non-small-cell lung cancer: a ten-year experience with vinblastine, cisplatin, and radiation therapy. Clin Lung Cancer (2010) 11:243-50. doi:10.3816/CLC.2010.n.031

3. Vinod SK, Wai E, Alexander C, Tyldesley S, Murray N. Stage III non-smallcell lung cancer: population-based patterns of treatment in British Columbia, Canada. J Thorac Oncol (2012) 7:1155-63. doi:10.1097/JTO.0b013e31824fea07

4. Lee PN, Forey BA, Coombs KJ. Systematic review with meta-analysis of the epidemiological evidence in the 1900 s relating smoking to lung cancer. BMC Cancer (2012) 12:385. doi:10.1186/1471-2407-12-385

5. Smith BM, Schwartzman K, Kovacina B, Taylor J, Kasymjanova G, Brandao G, et al. Lung cancer histologies associated with emphysema on computed tomography. Lung Cancer (2012) 76:61-6. doi:10.1016/j.lungcan.2011.09.003

6. Sigel CS, Moreira AL, Travis WD, Zakowski MF, Thornton RH, Riely GJ, et al. Subtyping of non-small cell lung carcinoma: a comparison of small biopsy and cytology specimens. J Thorac Oncol (2011) 6:1849-56. doi:10.1097/JTO. 0b013e318227142d

7. Travis WD, Brambilla E, Noguchi M, Nicholson AG, Geisinger K, Yatabe Y, et al. International association for the study of lung cancer/American thoracic society/European respiratory society international multidisciplinary classification of lung adenocarcinoma. J Thorac Oncol (2011) 6:244-85. doi:10.1097/JTO. 0b013e318206a221

8. Jerome Marson V, Mazieres J, Groussard O, Garcia O, Berjaud J, Dahan M, et al. Expression of TTF-1 and cyto-keratins in primary and secondary epithelial tumors: correlation with histological type and grade. Histopathology (2004) 45(2):125-35. doi:10.1111/j.1365-2559.2004.01893.x

9. Warth A, Muley T, Herpel E, Meister M, Herth FJ, Schirmacher P, et al. Large-scale comparative analyses of immunomarkers for diagnostic subtyping of non-small-cell lung cancer biopsies. Histopathology (2012) 61:1017-25. doi:10.1111/j.1365-2559.2012.04308.x

10. Ring BZ, Seitz RS, Beck RA, Shasteen WJ, Soltermann A, Arbogast S, et al. A novel five-antibody immunohistochemical test for subclassification of lung carcinoma. Mod Pathol (2009) 22:1032-43. doi:10.1038/modpathol.2009.60

11. Fang W, Zhang J, Liang W, Huang Y, Yan Y, Wu X, et al. Efficacy of epidermal growth factor receptor-tyrosine kinase inhibitors for Chinese patients with squamous cell carcinoma of lung harboring EGFR mutation. J Thorac Dis (2013) 5:582-92. doi:10.3978/j.issn.2072-1439.2013.09.15

12. Hata A, Katakami N, Yoshioka H, Kunimasa K, Fujita S, Kaji R, et al. How sensitive are epidermal growth factor receptor-tyrosine kinase inhibitors for squamous cell carcinoma of the lung harboring EGFR gene-sensitive mutations? J Thorac Oncol (2013) 8:89-95. doi:10.1097/JTO.0b013e31827690b5

13. Caliò A, Nottegar A, Gilioli E, Bria E, Pilotto S, Peretti U, et al. ALK/EML4 fusion gene may be found in pure squamous carcinoma of the lung. J Thorac Oncol (2013) 9:729-32. doi:10.1097/JTO.0000000000000109

14. Wang R, Pan Y, Li C, Zhang H, Garfield D, Li Y, et al. Analysis of major known driver mutations and prognosis in resected adenosquamous lung carcinomas. $J$ Thorac Oncol (2014). doi:10.1097/JTO.0b013e3182a406d1

15. Dearden S, Stevens J, Wu YL, Blowers D. Mutation incidence and coincidence in non-small cell lung cancer: meta-analyses by ethnicity and histology (mutMap). Ann Oncol (2013) 24:2371-6. doi:10.1093/annonc/mdt205
16. Timar J. The clinical relevance of KRAS gene mutation in non-smallcell lung cancer. Curr Opin Oncol (2014) 26:138-44. doi:10.1097/CCO. 0000000000000051

17. Shepherd FA, Rodrigues Pereira J, Ciuleanu T, Tan EH, Hirsh V, Thongprasert $\mathrm{S}$, et al. Erlotinib in previously treated non-small-cell lung cancer. $N$ Engl J Med (2005) 353:123-32. doi:10.1056/NEJMoa050753

18. Cancer Genome Atlas Research Network. Comprehensive genomic characterization of squamous cell lung cancers. Nature (2012) 489(7417):519-25. doi:10.1038/nature11404

19. Hecht SS. Lung carcinogenesis by tobacco smoke. Int J Cancer (2012) 131:2724-32. doi:10.1002/ijc. 27816

20. Salgia R. Fibroblast growth factor signaling and inhibition in non-small cell lung cancer and their role in squamous cell tumors. Cancer Med (2014). doi:10.1002/cam4.238

21. Reck M, Kaiser R, Mellemgaard A, Douillard JY, Orlov S, Krzakowski M, et al. Docetaxel plus nintedanib versus docetaxel plus placebo in patients with previously treated non-small-cell lung cancer (LUME-Lung 1): a phase 3, double-blind, randomised controlled trial. Lancet Oncol (2014) 15:143-55. doi:10.1016/S1470-2045(13)70586-2

22. Laurie SA, Solomon BJ, Seymour L, Ellis PM, Goss GD, Shepherd FA, et al. Randomised, double-blind trial of carboplatin and paclitaxel with daily oral cediranib or placebo in patients with advanced non-small cell lung cancer: NCIC Clinical Trials Group study BR29. Eur J Cancer (2014) 50:706-12. doi:10.1016/j.ejca.2013.11.032

23. Davidson B, Secord AA. Profile of pazopanib and its potential in the treatment of epithelial ovarian cancer. Int J Womens Health (2014) 6:289-300. doi:10.2147/IJWH.S49781

24. Heist RS, Mino-Kenudson M, Sequist LV, Tammireddy S, Morrissey L, Christiani DC, et al. FGFR1 amplification in squamous cell carcinoma of the lung. J Thorac Oncol (2012) 7:1775-80. doi:10.1097/JTO.0b013e31826aed28

25. Clark GM, Zborowski DM, Santabarbara P, Ding K, Whitehead M, Seymour L, et al. Smoking history and epidermal growth factor receptor expression as predictors of survival benefit from erlotinib for patients with non-small-cell lung cancer in the National Cancer Institute of Canada Clinical Trials Group study BR.21. Clin Lung Cancer (2006) 7:389-94. doi:10.3816/CLC.2006.n.022

26. van Boerdonk RA, Daniels JM, Bloemena E, Krijgsman O, Steenbergen RD, Brakenhoff RH, et al. High-risk human papillomavirus-positive lung cancer: molecular evidence for a pattern of pulmonary metastasis. J Thorac Oncol (2013) 8:711-8. doi:10.1097/JTO.0b013e3182897c14

27. Heist RS, Sequist LV, Engelman JA. Genetic changes in squamous cell lung cancer: a review. J Thorac Oncol (2012) 7:924-33. doi:10.1097/JTO.0b013e31824cc334

28. Spigel DR, Ervin TJ, Ramlan R, Daniel DB, Goldschmidt JH, Blumenschein GR, et al. Final efficacy results from OAM558g, a randomized phase II study evaluating MetMAb or placebo in combination with erlotinib in advanced NSCLC. $J$ Clin Oncol (2013) 29(Suppl):Abstr7505. doi:10.1200/JCO.2012.47.4189

29. Zhu CQ, da Cunha Santos G, Ding K, Sakurada A, Cutz JC, Liu N, et al. Role of KRAS and EGFR as biomarkers of response to erlotinib in National Cancer Institute of Canada Clinical Trials Group Study BR.21. J Clin Oncol (2008) 26:4268-75. doi:10.1200/JCO.2007.14.8924

30. Ellis PM, Morzycki W, Melosky B, Butts C, Hirsh V, Krasnoshtein F, et al. The role of the epidermal growth factor receptor tyrosine kinase inhibitors as therapy for advanced, metastatic, and recurrent non-small-cell lung cancer: a Canadian national consensus statement. Curr Oncol (2009) 16:27-48. doi:10.3747/co.v16i1.393

31. Kim ES, Hirsh V, Mok T, Socinski MA, Gervais R, Wu YL, et al. Gefitinib versus docetaxel in previously treated non-small-cell lung cancer (INTEREST): a randomised phase III trial. Lancet (2008) 372:1809-18. doi:10.1016/S01406736(08)61758-4

32. Pirker R, Pereira JR, von Pawel J, Krzakowski M, Ramlau R, Park K, et al. EGFR expression as a predictor of survival for first-line chemotherapy plus cetuximab in patients with advanced non-small-cell lung cancer: analysis of data from the phase 3 FLEX study. Lancet Oncol (2012) 13:33-42. doi:10.1016/S1470-2045(11) 70318-7

33. Douillard JY, Pirker R, O’Byrne KJ, Kerr KM, Störkel S, von Heydebreck A, et al. Relationship between EGFR expression, EGFR mutation status, and the efficacy of chemotherapy plus cetuximab in FLEX study patients with advanced non-small-cell lung cancer. J Thorac Oncol (2014) 9:717-24. doi:10.1097/JTO. 0000000000000141 
34. Thatcher N, Hirsch FR, Szczesna A, Ciuleanu TE, Szafranski W, Dediu M, et al. A randomized, multicenter, open-label, phase III study of gemcitabine, cisplatin (GC) chemotherapy plus necitumumab (IMC-11F8/LY3012211) versus GC alone in the first line treatment of patients with stage IV squamous nonsmall cell carcinoma. J Clin Oncol (2014) 32(Suppl: Abs 8008):55.

35. Goss G, Felip E, Cobo M, et al. A Randomized, Open-Label, Phase III Trial of Afatinib vs. Erlotinib as Second-Line Treatment of Patients with Advanced Squamous Cell Carcinoma of the Lung Following First-Line Platinum-Based Chemotherapy: Lux-Lung 8. ESMO preferred paper section (2014). abstr12220 p.

36. Piperdi B, Merla A, Perez-Soler R. Targeting angiogenesis in squamous non-small cell lung cancer. Drugs (2014) 74:403-13. doi:10.1007/s40265-014-0182-Z

37. Johnson DH, Fehrenbacher L, Novotny WF, Herbst RS, Nemunaitis JJ, Jablons DM, et al. Randomized phase II trial comparing bevacizumab plus carboplatin and paclitaxel with carboplatin and paclitaxel alone in previously untreated locally advanced or metastatic non-small-cell lung cancer. J Clin Oncol (2004) 22:2184-91. doi:10.1200/JCO.2004.11.022

38. Garon EB, Ciuleanu TE, Arrieta O, Prabhash K, Syrigos KN, Goksel T, et al. Ramucirumab plus docetaxel versus placebo plus docetaxel for second-line treatment of stage IV non-small-cell lung cancer after disease progression on platinum-based therapy (REVEL): a multicentre, double-blind, randomised phase 3 trial. Lancet (2014) 384(9944):665-73. doi:10.1016/S0140-6736(14) 60845-X

39. Novello S, Scagliotti GV, Sydorenko O, Vynnychenko I, Volovat C, Schneider CP, et al. Motesanib plus carboplatin/paclitaxel in patients with advanced squamous non-small-cell lung cancer: results from the randomized controlled MONET1 study. J Thorac Oncol (2014) 9:1143-51. doi:10.1097/JTO. 0000000000000227

40. Parkes SK, Chiche J, Pouyssegur J. Disrupting protein dynamics and energy metabolism for cancer therapy. Nat Rev Cancer (2013) 13:611-23. doi:10.1038/ nrc3579

41. Topasalian SL, Weiner GJ, Pardoll DM. Cancer immunotherapy comes of age. J Clin Oncol (2011) 29:4828-36. doi:10.1200/JCO.2011.38.0899

42. Chen DS, Mellman I. Oncology meets immunology: the cancer-immunity cycle. Immunity (2013) 39:1-10. doi:10.1016/j.immuni.2013.07.012

43. Lynch TJ, Bondarenko I, Luft A, Serwatowski P, Barlesi F, Chacko R, et al. Ipilimumab in combination with paclitaxel and carboplatin as first-line treatment in stage IIIB/IV non-small-cell lung cancer: results from a randomized, double-blind, multicenter phase II study. J Clin Oncol (2012) 30:2046-54. doi:10.1200/JCO.2011.38.4032

44. Topalian SL, Hodi FS, Brahmer JR, Gettinger SN, Smith DC, McDermott DF, et al. Safety, activity, and immune correlates of anti-PD-1 antibody in cancer. $N$ Engl J Med (2012) 366:2443-54. doi:10.1056/NEJMoa1200690

45. Brahmer JR, Tykodi SS, Chow LQ, Hwu WJ, Topalian SL, Hwu P, et al. Safety and activity of anti-PD-L1 antibody in patients with advanced cancer. $\mathrm{N} \mathrm{Engl} \mathrm{J}$ Med (2012) 366:2455-65. doi:10.1056/NEJMoa1200694

46. Horn L, et al. Abstract MO148.01.2013. Available from: http://www.webges. com/cview/library/wclc/home

47. Stinchcombe TE. Unmet needs in squamous cell carcinoma of the lung: potential role for immunotherapy. Med Oncol (2014) 31(5):960. doi:10.1007/s12032014-0960- 1

48. Langer CJ. Emerging immunotherapies in the treatment of non-small cell lung cancer (NSCLC): the role of immune checkpoint inhibitors. Am J Clin Oncol (2014). doi:10.1097/COC.0000000000000059

49. Rosen LS, Gordon D, Tchekmedyian NS, Yanagihara R, Hirsh V, Krzakowski M, et al. Long-term efficacy and safety of zoledronic acid in the treatment of skeletal metastases in patients with non-small cell lung carcinoma and other solid tumors: a randomized, phase III, double-blind, placebo-controlled trial. Cancer (2004) 100:2613-21. doi:10.1002/cncr.20308

50. Hirsh V, Tchekmedyian NS, Rosen LS, Zheng M, Hei YJ. Clinical benefit of zoledronic acid in patients with lung cancer and other solid tumors: analysis based on history of skeletal complications. Clin Lung Cancer (2004) 6:190-4. doi:10.3816/CLC.2004.n.030

51. Hirsh V, Major PP, Lipton A, Cook RJ, Langer CJ, Smith MR, et al. Zoledronic acid and survival in patients with metastatic bone disease from lung cancer and elevated markers of osteoclast activity. J Thorac Oncol (2008) 3:228-36. doi:10.1097/JTO.0b013e3181651c0e

52. Scagliotti GV, Hirsh V, Siena S, Henry DH, Woll PJ, Manegold C, et al. Overall survival improvement in patients with lung cancer and bone metastases treated with denosumab versus zoledronic acid: subgroup analysis from a randomized phase 3 study. J Thorac Oncol (2012) 7:1823-91. doi:10.1097/JTO.0b013e31826aec2b

53. Henry D, Vadhan-Raj S, Hirsh V, von Moos R, Hungria V, Costa L, et al. Delaying skeletal-related events in a randomized phase 3 study of denosumab versus zoledronic acid in patients with advanced cancer: an analysis of data from patients with solid tumors. Support Care Cancer (2014) 2:679-87. doi:10.1007/s00520-013-2022-1

54. Hoang T, Dahlberg SE, Schiller JH, Johnson DH. Does histology predict survival of advanced non-small cell lung cancer patients treated with platinbased chemotherapy? An analysis of the Eastern Cooperative Oncology Group Study E1594. Lung Cancer (2012) 81:47-52. doi:10.1016/j.lungcan.2013. 03.018

55. Scagliotti GV, Parikh P, von Pawel J, Biesma B, Vansteenkiste J, Manegold C, et al. Phase III study comparing cisplatin plus gemcitabine with cisplatin plus pemetrexed in chemotherapy-naive patients with advanced-stage non-small-cell lung cancer. J Clin Oncol (2008) 26:3543-51. doi:10.1200/JCO.2007.15.0375

56. Scagliotti G, Hanna N, Fossella F, Sugarman K, Blatter J, Peterson P, et al. The differential efficacy of pemetrexed according to NSCLC histology: a review of two phase III studies. Oncologist (2009) 14:253-63. doi:10.1634/theoncologist. 2008-0232

57. Ciuleanu T, Brodowictz T, Zielinski C, Kim JH, Krzakowski M, Laack E, et al. Maintenance pemetrexed plus best supportive care versus placebo plus best supportive care for non-small-cell lung cancer: a randomised, double-blind, phase 3 study. Lancet (2009) 374:1432-40. doi:10.1016/S0140-6736(09)61497-5

58. Liu Y, Yin TJ, Zhou R, Zhou S, Fan L, Zhang RG. Expression of thymidylate synthase predicts clinical outcomes of pemetrexed-containing chemotherapy for non-small-cell lung cancer: a systemic review and meta-analysis. Cancer Chemother Pharmacol (2013) 72:1125-32. doi:10.1007/s00280-013-2299-2

59. Ceppi P, Volante M, Saviozzi S, Rapa I, Novello S, Cambieri A, et al. Squamous cell carcinoma of the lung compared with other histotypes shows higher messenger RNA and protein levels for thymidylate synthase. Cancer (2006) 107:1589-96. doi:10.1002/cncr.22208

60. Nunez MI, Behrens C, Woods DM, Lin H, Suraokar M, Kadara H, et al. High expression of folate receptor alpha in lung cancer correlates with adenocarcinoma histology and EGFR [corrected] mutation. J Thorac Oncol (2012) 7:833-60. doi:10.1097/JTO.0b013e31824de09c

61. Socinkski MA, Okamoto I, Hon JK, Hirsh V, Dakhil SR, Page RD, et al. Safety and efficacy analysis by histology of weekly nab-paclitaxel in combination with carboplatin as first-line therapy in patients with advanced non-small-cell lung cancer. Ann Oncol (2013) 24:2390-6. doi:10.1093/annonc/mdt235

62. Hirsh V. Nab-paclitaxel for the management of patients with advanced nonsmall-cell lung cancer. Expert Rev Anticancer Ther (2014) 14:129-41. doi:10. 1586/14737140.2014.881719

63. Yoshioka H, Okamoto I, Morita S, Ando M, Takeda K, Seto T, et al. Efficacy and safety analysis according to histology for S-1 in combination with carboplatin as first-line chemotherapy in patients with advanced non-small-cell lung cancer: updated results of the West Japan Oncology Group LETS study. Ann Oncol (2012) 24:1326-31. doi:10.1093/annonc/mds629

64. O'Sullivan CC, Moon DH, Kohn EC, Lee JM. Beyond breast and ovarian cancers: PARP inhibitors for BRCA mutation-associated and BRCA-like solid tumors. Front Oncol (2014) 4:2-13. doi:10.3389/fonc.2014.00042

65. Levra MG, Olaussen KA, Novello S, Soria JC. PARP inhibitors: an interesting pathway also for non-small cell lung cancer? Curr Pharm Des (2013).

66. Ramalingam SS, Blais N, Mazieres J, Reck M, Jones CM, Juhasz E, et al. A Randomized, Double Blind, Phase 2 Trial of Veliparib (ABT-888) with Carboplatin and Paclitaxel in Previously Untreated Metastatic (or Advanced Non-Small Cell Lung Cancers. Poster Display Session, ESMO (2014). Abstr1234 p.

67. Sinha GJ. Downfall of iniparib: a PARP inhibitor that doesn't inhibit PARP after all. J Natl Cancer Inst (2014) 106:1. doi:10.1093/jnci/djt447

68. July LV, Beraldi E, So A, Fazli L, Evans K, English JC, et al. Nucleotide-based therapies targeting clusterin chemosensitize human lung adenocarcinoma cells both in vitro and in vivo. Mol Cancer Ther (2004) 3:228-32.

69. Niu L, Zang J, Cai L, Li C, Cao H. Relationship of clusterin expression with Bax and p53 expression in non-small cell lung cancer. Zhongguo Fei Ai Za Zhi (2007) 10:284-7. doi:10.3779/j.issn.1009-3419.2007.04.05

70. Dwyer-Lindgren L, Mokdad AH, Srebotnjak T, Flaxman AD, Hansen GM, Murray CJ. Cigarette smoking prevalence in US counties: 1996-2012. Popul Health Metr (2014) 12:5. doi:10.1186/1478-7954-12-5 
71. Callaghan RC, Allebeck P, Sidorchuk A. Marijuana use and risk of lung cancer: a 40-year cohort study. Cancer Causes Control (2013) 24:1811-20. doi:10.1007/s10552-013-0259-0

Conflict of Interest Statement: The author declares that the research was conducted in the absence of any commercial or financial relationships that could be construed as a potential conflict of interest.

Received: 02 June 2014; accepted: 26 October 2014; published online: 09 December 2014.
Citation: Vincent MD (2014) Promising targets and current clinical trials in metastatic squamous cell lung cancer. Front. Oncol. 4:320. doi: 10.3389/fonc.2014.00320

This article was submitted to Thoracic Oncology, a section of the journal Frontiers in Oncology.

Copyright (C) 2014 Vincent. This is an open-access article distributed under the terms of the Creative Commons Attribution License (CC BY). The use, distribution or reproduction in other forums is permitted, provided the original author(s) or licensor are credited and that the original publication in this journal is cited, in accordance with accepted academic practice. No use, distribution or reproduction is permitted which does not comply with these terms. 